\title{
МЕХАНИЗМ ИММУНОБИОЛОГИЧЕСКОЙ ТОЛЕРАНТНОСТИ ВО ВРЕМЯ БЕРЕМЕННОСТИ В ФУНКЦИОНАЛЬНОЙ СИСТЕМЕ «МАТЬ-ПЛОД-НОВОРОЖДЕННЫЙ»
}

\section{A. V. Agarkov, A. F. Dmitriev, A. N. Kvochko, N. V. Agarkov \\ THE MECHANISM OF IMMUNOBIOLOGICAL TOLERANCE DURING PREGNANCY IN 'MOTHER- FETUS-NEWBORN' FUNCTIONAL SYSTEM}

Агарков Александр Викторович - канд. биол. наук, доц. каф. терапии и фрармакологии Ставропольского государственного аграрного университета, г. Ставрополь. E-mail: agarkov_a.v@mail.ru Дмитриев Анатолий федорович - д-р биол. наук, проф. каф. эпизоотологии и микробиологии Ставропольского государственного аграрного университета, г. Ставрополь. E-mail: fvmstgau@mail.ru Квочко Андрей Николаевич - д-р биол. наук, проф. РАН, проф. каф. фризиологии, хирургии и акушерства Ставропольского государственного аграрного университета, г. Ставрополь.

E-mail: kvochko@yandex.ru

Агарков Николай Викторович - канд. биол. наук, ассист. каф. паразитологии и ветсанэкспертизы, анатомии и патанатомии им. проф. С.Н. Никольского Ставропольского государственного аграрного университета, г. Ставрополь.

E-mail: agarckov.nickolay@yandex.ru

Цель исследования - установить и оценить механизмы формирования иммунологической толерантности в системе «мать-плодноворожденный», ее специфрических свойств под непосредственным влиянием естественных антигенных стимулов. Исследования проводили в производственных условиях свиноводческого комплекса «Штурм» Красногвардейского района Ставропольского края на свиньях крупной белой породы. Для проведения исследования от 20 свиноматок первого опороса были отобраны поросята - 90 голов в неонатальный период. Методикой исследования предусматривалась иммунизация свиноматок экстрактами сперматозоидов и плазмой семени. Экстракты ксеногенных сперматозоидов готовили по общепринятой методике и иммунизировали ими животных под конъюнктиву глазного века, а полный адъювант вводили внутримы-
Agarkov Alexander Victorovich - Cand. Biol. Sci., Assoc. Prof., Chair of Therapy and Pharmacology, Stavropol State Agrarian University, Stavropol.

E-mail: agarkov_a.v@mail.ru

Dmitriev Anatoly Fedorovich - Dr. Biol. Sci., Prof., Chair of Epizootology and Microbiology, Stavropol State Agrarian University, Stavropol.

E-mail: fvmstgau@mail.ru

Kvochko Andrey Nikolaevich - Dr. Biol. Sci., Prof. RAS, Prof., Chair of Physiology, Surgery and Obstetrics, Stavropol State Agrarian University, Stavropol.

E-mail: kvochko@yandex.ru

Agarkov Nikolay Victorovich - Cand. Biol. Sci., Asst, Chair of Parasitology and Veterinary Sanitary Inspection, Anatomy and Pathological Anatomy named after Prof. S. N. Nikolsky, Stavropol State Agrarian University, Stavropol.

E-mail: agarckov.nickolay@yandex.ru

шечно. Других животных иммунизировали плазмой семени по той же схеме. Циклы иммунизации состояли из трех ежедневных инъекций по 0,3 мл для экстракта сперматозоидов и по 0,05 мл для плазмы семени (около 4 ма белка). Проводили три цикла иммунизации с интервалами 2 дня для экстрактов сперматозоидов и 3 дня для плазмы семени. После завершения иммунизации оценивали ее эфрфективность методом преципитации в агаре. По результатам исследования выявлены следующие варианты наступления толерантности. Во-первых, преобладающее влияние лимсоцитов T-супрессоров, которые появляются в большем числе в период беременности и препятствуют распознающей функции лимфоцитов Т-помощников, а также синтезу антител либо бласттрансформации В-лимсроцитов. Эти процессы проходят под непосредственным влиянием сигна- 
лов от костномозговых клеток и вследствие регуляции со стороны гипоталамо-гипосизоадрено-кортикальной оси. Во-вторых, установлению толерантности в системе «мать-плод» способствует свойство крови при беременности подавлять активность лимфоцитов, которое появляется в ходе развития продуктов оплодотворения.

Ключевые слова: иммунобиологический статус, иммунологическая реактивность, феномен конкуренции антигенов, беременные животныL.

The research objective was to establish and estimate the mechanisms of the formation of immunological tolerance in 'mother-fetus-newborn' system, its specific properties under direct influence of natural anti-gene incentives. The researches were conducted under production conditions of pig-breeding complex 'Shturm' of Krasnogvardeisk district of Stavropol Region on the pigs of large white breed. For carrying out the research from 20 sows of the first farrow the pigs of 90 heads during their neonatal period were selected. The technique of the research provided the immunization of the sows by the extracts of spermatozoa and semen plasma. The extracts of xenogen spermatozoa were prepared by the standard technique and the animals were immunized under the conjunctiva of an eye eyelid, and full adjuvant was entered intramuscularly. Other animals were immunized with semen plasma according to the same scheme. The cycles of immunization consisted of three daily injections on $0.3 \mathrm{ml}$ for extract of spermatozoa and on $0.05 \mathrm{ml}$ for semen plasma (about $4 \mathrm{mg}$ of protein). Three cycles of immunization with 2 days intervals for the extracts of spermatozoa and 3 days for semen plasma were carried out. After the completion of the immunization its efficiency by precipitation method in agar was estimated. By the results of the research the following options of tolerance approach were revealed. First, the influence of lymphocytes $T$-suppressors was prevailing appearing in larger number during pregnancy and interfered with distinguishing the function of lymphocytes of $T$ assistants, and also the synthesis of antibodies or blast transformation of V-lymphocytes. These processes appeared under direct influence of the signals from marrowy cells and owing to the regulation from outside hypothalamus-hypoadrenal-cortical axes. Secondly, the establishment of tolerance in mother-fetus system was promoted by the property of blood at pregnancy to suppress the activity of lymphocytes which appeared in the process of products of fertilization.

Keywords: immunobiological status, immunological reactivity, antigen competition phenomenon, pregnant animals.

Введение. Иммунобиологический статус новорожденных животных в большей степени зависит от материнского организма. Вместе с тем вопросы иммунологической толерантности между состоянием материнского организма и здоровьем новорожденного животного пока не нашли полного отражения в исследованиях. Почти не изучены аспекты, связанные с характером иммунного реагирования на антигены плода. Сведения о влиянии иммунологических фракторов материнского организма на уровень морфофункционального развития плода и жизнеспособность новорожденного ограничены сообщениями о некоторых заболеваниях, обусловленных иммуногенетической несовместимостью. Знание закономерностей развития иммунных процессов, которые зависят от степени сходства и различия между организмом матери и плода по антигенам гистиеовместимости, может способствовать разрешению многих теоретических и практических аспектов проблемы онтогенеза.

Цель исследования: установить и оценить механизмы формирования иммунологической толерантности в системе «мать-плод-новорожденный», ее специфические свойства под непосредственным влиянием естественных антигенных стимулов.

\section{Задачи исследования:}

1. Изучить закономерности формирования иммуноопосредованных процессов функциональной системы «мать-плод-новорожденный» с ранних сроков беременности.

2. Выявить критерии нарушения иммунорегуляции и иммунологической толерантности при беременности.

3. Определить механизмы формирования иммунопатологии у новорожденных животных.

Объекты, материалы и методы исследования. Исследование проводили в производственных условиях свиноводческого комплекса «Штурм» Красногвардейского района Ставропольского края на свиньях крупной белой породы. Объектом исследования выступали свиноматки, выбранные путем случайной выборки в полевых условиях. Для проведения исследова- 
ния от 20 свиноматок первого опороса были отобраны поросята 90 голов в неонатальный период.

Свиноматок иммунизировали экстрактами сперматозоидов либо плазмой семени. Экстракты ксеногенных сперматозоидов готовили по общепринятой методике и иммунизировали ими крольчих под конъюнктиву глазного века, а полный адъювант вводили внутримышечно $[2,4,5]$. Других животных иммунизировали плазмой семени по той же схеме. Циклы иммунизации состояли из трех ежедневных инъекций по 0,3 мл для экстракта сперматозоидов и по 0,05 мл для плазмы семени (около 4 мг белка). Проводили три цикла иммунизации с интервалами 2 дня для экстрактов сперматозоидов и 3 дня для плазмы семени.

После окончания иммунизации проверяли ее эфффективность методом преципитации в агаре $[3,8]$. Гистологические срезы окрашивали гематоксилином и эозином, соединительную ткань выявляли методами Ван Гизона, Вейгерта, Маллори, согласно рекомендациям, изложенным в руководстве В.В. Семченко с соавт. (2006). Для световой микроскопии брали образцы тимуса, костного мозга (бедра), подколенных лимфоуз- лов, селезенки и печени (у крольчих) на 7-10-й день после иммунизации у небеременных и на 17-22-й день у беременных животных. Для просвечивающей и сканирующей микроскопии образцы тканей фиксировали в 3 \%-м растворе глютаральдегида на фосфратном буфере при pH 7,3 c 0,1 М сахарозой в течение 2 ч, промывали фоссратным буфрером и фиксировали по Милонигу в течение 1 ч [6, 7]; обезвоживали в эталонах возрастающей крепости до $100^{\circ}$. Окрашенные и промытые в воде срезы обезвоживали в спиртах $\left(70^{\circ}, 96^{\circ}\right)$, просветляли в ксилоле, а затем исследовали на предметном стекле. Все гистологические и иммуногистохимические исследования препаратов проведены с помощью светового микроскопа OLYMPUS-BX 43 (Япония) и фотоаппарата OLYMPUS C 300 (Япония).

Результаты исследования и их обсуждение. В каждом поле зрения микроскопа даже без подсчета можно отчетливо видеть разницу между иммунологической реактивностью беременных и небеременных особей, судя по числу лимфоцитов, свободных или почти свободных и с налипшими на них частицами; лимфоцитов (розетки) вдвое больше у беременных, чем у интактных особей (табл. 1).

Таблица 1

\section{Пропорция Т-лимфоцитов с различным числом налипшихна них частиц вне организма при беременности}

\begin{tabular}{|c|c|c|c|}
\hline \multirow{2}{*}{ Свиноматки } & \multirow{2}{*}{ 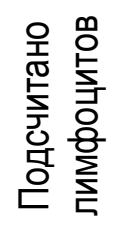 } & \multicolumn{2}{|c|}{ Из них с числом эритроцитов, \% } \\
\hline & & 1-я группа & 2-я группа \\
\hline Беременные & 943 & $25,2 \pm 0,14^{*}$ & $65,4+0,15$ \\
\hline Небеременные & 233 & $68,1 \pm 0,30$ & $30,7+0,22^{* *}$ \\
\hline
\end{tabular}
${ }^{*} p<0,05 ;{ }^{* *} p<0,01$.

Поведение Т-лимфоцитов по отношению к ксеногенным эритроцитам барана, использованным для данной цели, мы назвали ТЭреакцией (тимоцит-эритроцит).

Предположение о влиянии на ТЭ-реакцию изменения свойства Т-лимфоцитов в результате иммунных процессов в организме беременной самки было проверено сравнением реакции Тлимфоцитов у иммунизированных беременных самок с контролями (неиммунизированные и небеременные).
Сопоставление распределения лимфоцитов по числу прилипших к ним эритроцитов в ТЭреакции показало сходство влияния беременности и иммунизации самок живчиками того же самца, от которого получены эмбрионы. Сходство это, во-первых, означает иммуногенность эмбрионов по отношению к материнскому организму, а во-вторых, частичное антигенное сходство отцовских гамет и эмбрионов, обнаружимое по их действию на активность рецепторов, распознающих Т-лимфоциты (табл. 2). 
Численная характеристика способности Т-лимфоцитов агглютинировать ксеногенные эритроциты барана при беременности и иммунизации

\begin{tabular}{|c|c|c|c|c|}
\hline \multirow{2}{*}{ Самки } & \multirow{2}{*}{ 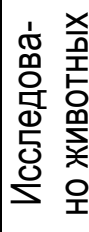 } & \multirow{2}{*}{ 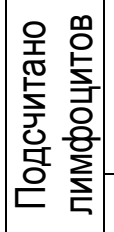 } & \multicolumn{2}{|c|}{ Из них с числом эритроцитов, \% } \\
\hline & & & 1-я группа & 2-я группа \\
\hline $\begin{array}{l}\text { Иммунизированные } \\
\text { (беременные } \\
\text { и небеременные) }\end{array}$ & 5 & 111 & $67,03 \pm 0,45$ & $30,22 \pm 0,43$ \\
\hline $\begin{array}{l}\text { Беременные } \\
\text { неиммунизированные }\end{array}$ & 5 & 153 & $78 \pm 0,13$ & $18,11 \pm 0,31$ \\
\hline $\begin{array}{l}\text { Неиммунизированные } \\
\text { и небеременные }\end{array}$ & 10 & 158 & $40,32 \pm 0,19^{*}$ & $2,0 \pm 0,36$ \\
\hline
\end{tabular}

${ }^{*} p<0,05$.

У всех свиноматок с установленной впоследствии беременностью число лимфоцитов с розетками достигло $70 \%$ против $9 \%$ у неосемененных особей. Суть реакции заключается, повидимому, в активизации большего числа рецепторов тимоцитов под влиянием беременности.

Реакция эта требует определенных условий, так как на нее действуют многие факторы. Привлекать к себе эритроциты могут только метаболически активные лимфоциты с неповрежденной структурой и при соответствующих температурных условиях. Наше мнение, что розетки могут формироваться и независимо от иммунных явлений. Иммунизация повышает число лимфоцитов в периферической крови, способных привлекать на свою поверхность ксеногенные эритроциты, а также увеличивает число бляшкообразующих клеток. Таким образом, по взаимодействию клеток крови можно судить об иммунном состоянии организма. Т-лимфоциты супоросных свиноматок по способности привлекать к себе ксеногенные эритроциты: до 30 \% лимфоцитов спонтанно реагируют на эритроциты барана.

Установление высокой иммуногенности поздних бластоцист и ранних эмбрионов у свиноматок натолкнуло на поиски наличия антител к ранним эмбрионам в сыворотке крови беременных самок. Эти антитела могут не повреждать эмбрион, огражденный гематогенитальным барьером, но циркулировать в крови, хотя и в незначительном титре.

Следовательно, при соединении вне организма с частицами, нагруженными эмбриональ- ным антигеном, сыворотка беременных самок вызывает агглютинацию этих частиц.

В наших опытах исследования сывороток крови от 20 свиноматок в сроки 25-30 дней после осеменения показали, что в 98 \% образцов сыворотки крови действительно беременных животных (что установлено с помощью УЗИ аппарата через 1 месяц) произошла агглютинация частиц, нагруженных эмбриональными антигенами.

В данном опыте антигеном нагружали отмытые эритроциты барана. Эта реакция предложена нами и названа ЭСЭ (эмбрион-сывороткаэритроцит). Различие между беременными и небеременными животными в ЭСЭ-реакции хорошо визуализируется. Для реакции использовали пластмассовые пластины с луночками, что облегчало как постановку реакции при малых дозах материала, так и чтение реакции.

По результатам исследований более чем у $90 \%$ особей результат ЭСЭ-реакции совпадает с данными УЗИ исследования. Вместе с тем по образцам, взятым на 16-й день и позднее после осеменения, процент совпадения выше. При анализе результатов иммунологического исследования по тем свиноматкам, которые оказались действительно беременными, по сравнению с животными, у которых беременность не обнаружена, выявлена разница между этими животными (табл. 3).

Несовпадение составляет 10,6 \%. Это, повидимому, связано с ранней пренатальной гибелью в промежутке между иммунологическим и ректальным исследованиями. 


\section{ЭСЭ-реакция в разное время после осеменения}

\begin{tabular}{|l|c|c|c|c|c|}
\hline Животные & $\begin{array}{c}\text { Сроки ис- } \\
\text { следования, } \\
\text { сутки после } \\
\text { осеменения }\end{array}$ & $\begin{array}{c}\text { Исследовано } \\
\text { свиноматок }\end{array}$ & $\begin{array}{c}\text { Из них дали реак- } \\
\text { цию положительно }\end{array}$ & $\begin{array}{c}\text { Беременных } \\
\text { свиноматок }\end{array}$ & $\begin{array}{c}\text { Совпадение, } \\
\%\end{array}$ \\
\hline Беременные & $\begin{array}{c}\text { До 15-16 } \\
\text { и более }\end{array}$ & 80 & 67 & 62 & 92,3 \\
\hline Небеременные & - & 14 & 0 & 0 & 100,0 \\
\hline
\end{tabular}

Изучение основных структур лимфомиелоидной системы показало, что беременность, как и иммунизация, способствует значительному увеличению числа малых лимфоцитов в тимусе и местных лимфоузлах при статистически высоко достоверных различиях с контролями (небеременные и неиммунизированные самки). В том же направлении меняется при беременности пропорция лимфоцитов в клеточном пуле костного мозга. Следовательно, беременность направляет, как и нарочитая иммунизация, в определенные периоды лимфомиелоидную систему на увеличение в ней пропорции «распознающих» клеток иммунной системы (табл. 4).

\section{Изменение численности малых лимфоцитов в основных органах иммунной системы в связи с иммунизацией и беременностью}

\begin{tabular}{|l|c|c|c|c|}
\hline \multirow{2}{*}{ Самки-крольчихи } & \multicolumn{2}{|c|}{ Костный мозг } & \multicolumn{2}{|c|}{ Тимус и лимфоузлы } \\
\cline { 2 - 5 } & $\begin{array}{c}\text { Подсчитано } \\
\text { клеток }\end{array}$ & $\begin{array}{c}\text { Из них тимо- } \\
\text { цитов, \% }\end{array}$ & $\begin{array}{c}\text { Подсчитано } \\
\text { клеток }\end{array}$ & $\begin{array}{c}\text { Из них лимфо- } \\
\text { цитов, \% }\end{array}$ \\
\hline $\begin{array}{l}\text { Иммунизированные беременные } \\
\text { и небеременные }\end{array}$ & 749 & $88 \pm 0,12^{*}$ & 1403 & $77 \pm 0,12^{*}$ \\
\hline Неиммунизированные: небеременные & 740 & $84 \pm 0,13$ & 1461 & $77 \pm 0,13$ \\
\hline Беременные (все) & 1337 & $88 \pm 0,09^{* *}$ & 2403 & $78 \pm 0,18$ \\
\hline Небеременные (все) & 402 & $64+0,24$ & 933 & $57 \pm 0,16^{*}$ \\
\hline
\end{tabular}

${ }^{*} p<0,05 ;{ }^{* *} p<0,01$.

Статистически достоверное увеличение числа лимфоцитов в клеточном пуле на третьей неделе беременности может быть объяснено снятием при этом угнетения с определенных участков генома, что активизирует определяемый им синтез энзимных и неэнзимных белков.

Установлено, что при изучении ультраструктур клеток лимфомиелоидной системы наблюдается повышение их функциональной активности при беременности и особенно в связи с иммунизацией. Наиболее характерны изменения В-лимфоцитов; у них увеличиваются и удлиняются плазматические выросты по сравнению с контролем. Поверхность Т-лимфоцитов, которая обычно бывает гладкой, также покрывается ворсинками. В цитоплазме лимфоцитов увеличивается число митохондрий, лизосом и других клеточных органелл. Изменяется также поверхность фагоцитирующих клеток по сравнению с контролем.

Для сочетания беременности и иммунизации характерно наличие в тканях лимфомиелоидной системы плазматических и бластных клеток с обилием хорошо выраженных цистерн эргастоплазматической сети.

Увеличение поверхности Т- и В-лимфоцитов, а также макрофагов и появление удлиненных выростов их цитоплазмы способствует контактам между этими тремя типами клеток в процессе иммунного ответа путем клеточной кооперации. В процессе передачи информации от распознающей клетки (Т-лимфоцит) к макрофагу между ними формируются отчетливо видимые цитоплазматические мостики.

Выводы. Полученные данные открывают перспективы для разработки методов раннего прогнозирования толерантного состояния в пе- 
риод беременности и ранний постнатальный период о новорожденных животных, это необходимое звено саморегулирования в процессе нормального эмбриогенеза. Вместе с тем противоречивое равновесие в системе «мать-плодноворожденный» неустойчиво и может перейти в состояние иммунного конфоликта.

Изучение иммунизированных беременных свиноматок показало, что в течение короткого периода преобразования бластоцист в эмбрионы в селезенке появляются спонтанные розетки, а в периферической плазме крови самки увеличивается процент Т-лимсоцитов, способных к розеткообразованию с весенсибилизированными отмытыми эритроцитами барана либо другими органическими частицами сходного диаметра при статистически высоко достоверных различиях.

Установлено, что темпы и степень совершенствования иммунной системы во многом определяются антигенным воздействием на организм, причем большое значение имеет фактор первой встречи организма с определенными иммунозависимым стимулом.

\section{Литература}

1. Anthony R.V., Limesand S.W., Jeckel K.M. Transcriptional regulation in the placenta during normal and compromised fetal growth // Biochem. Soc. Trans. 2011. V. 29, Pt. 2. P. 42-48.

2. Emmans G.F., Didham J.D. Modelling of growth and nutrition in different species // Current topics in veterinary medicine and animal science. 2018. V. 46. P. 13-21.

3. Heijnen C.J., Kavelaars A.B., Bailieux R.E. Endorphines and the immune system // Neuroendocrinol. fceff. 2008. V. 15, № 4. P. 206-218.

4. Kruse P.R. The importance of colostral immunoglobulins and their absorption from the intestinal of the newborn animals // Annales de recherches veterinaires. 2009. V. 14, № 4. P. 349-353.
5. Piccardo M.G. Purine metabolism and immunodeficiencies disease // Rev. cur. sci, med. Pharmacol. 2014. V 2, № 5. P. 151-154.

6. Roitt I.P. Essential immunology. Oxford: Blackwell Science, 1994. 448 p.

7. Rossant J.A., Cross J.C. Placental development: lessons from mouse mutants // Nat. Rev. Genet. 2018. V 2, № 7. P. 538-548.

8. Sharma A., Ford S., Calvert J. Adaptation for life: a review of neonatal physiology. Anaesth. Intens. Care Med., 2019. V 12, № 3. P. 85-90.

\section{Literatura}

1. Anthony R.V., Limesand S.W., Jeckel K.M. Transcriptional regulation in the placenta during normal and compromised fetal growth /I Biochem. Soc. Trans. 2011. V. 29, Pt. 2. P. 4248.

2. Emmans G.F., Didham J.D. Modelling of growth and nutrition in different species // Current topics in veterinary medicine and animal science. 2018. V. 46. P. 13-21.

3. Heijnen C.J., Kavelaars A.B., Bailieux R.E. Endorphines and the immune system // Neuroendocrinol. fceff. 2008. V. 15, № 4. P. 206-218.

4. Kruse P.R. The importance of colostral immunoglobulins and their absorption from the intestinal of the newborn animals // Annales de recherches veterinaires. 2009. V. 14, № 4. P. 349-353.

5. Piccardo M.G. Purine metabolism and immunodeficiencies disease // Rev. cur. sci, med. Pharmacol. 2014. V 2, № 5. P. 151-154.

6. Roitt I.P. Essential immunology. Oxford: Blackwell Science, 1994. 448 p.

7. Rossant J.A., Cross J.C. Placental development: lessons from mouse mutants // Nat. Rev. Genet. 2018. V 2, № 7. P. 538-548.

8. Sharma A., Ford S., Calvert J. Adaptation for life: a review of neonatal physiology. Anaesth. Intens. Care Med., 2019. V 12, № 3. P. 85-90. 